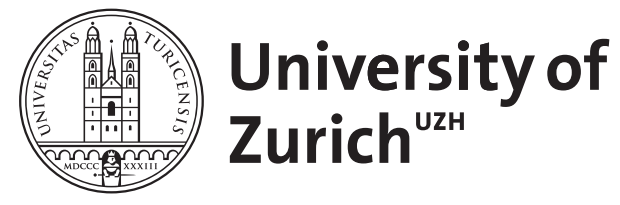

Failure to thrive and nephrolithiasis in a boy with congenital cyanotic heart anomaly

Tasic, V ; Lozanovski, V J ; Gucev, Z ; Blau, N ; Cheong, H I ; Sayer, J A

DOI: https://doi.org/10.1007/s00467-011-1786-0

Posted at the Zurich Open Repository and Archive, University of Zurich ZORA URL: https://doi.org/10.5167/uzh-56974

Journal Article

Published Version

Originally published at:

Tasic, V; Lozanovski, V J; Gucev, Z; Blau, N; Cheong, H I; Sayer, J A (2011). Failure to thrive and nephrolithiasis in a boy with congenital cyanotic heart anomaly. Pediatric Nephrology, 26(12):2153-2157. DOI: https://doi.org/10.1007/s00467-011-1786-0 


\title{
Failure to thrive and nephrolithiasis in a boy with congenital cyanotic heart anomaly-questions
}

\author{
Velibor Tasic • Vladimir J. Lozanovski • Zoran Gucev • \\ Nenad Blau • Hae Il Cheong • John A. Sayer
}

Received: 5 December 2010 /Revised: 20 January 2011 /Accepted: 21 January 2011 /Published online: 1 March 2011

(C) IPNA 2011

Keywords Cyanotic heart anomaly Metabolic acidosis . Failure to thrive $\cdot$ Nephrolithiasis

\section{Case summary}

A 3-year-old boy from Kosovo was referred to us for evaluation of failure to thrive and an episode of macro-

The answers to these questions can be found at http://dx.doi.org/ 10.1007/s00467-011-1790-4.

\footnotetext{
V. Tasic $(\bowtie) \cdot Z$. Gucev

Department of Pediatric Nephrology,

University Children's Hospital, Medical School Skopje,

17 Vodnjanska,

1000 Skopje, Macedonia

e-mail: vtasic2003@gmail.com

V. J. Lozanovski

Universitätsklinik für Allgemein-,

Viszeral- und Transplantationschirurgie, Universität Heidelberg,

Heidelberg, Germany

N. Blau

Division of Clinical Chemistry and Biochemistry,

University Children's Hospital Zürich,

Zürich, Switzerland

H. I. Cheong

Department of Pediatrics,

Seoul National University Children's Hospital,

Seoul, South Korea

\section{J. A. Sayer}

Institute of Human Genetics, International Centre for Life,

Newcastle University,

Newcastle, UK
}

scopic hematuria. He was the son of healthy nonconsanguineous parents. His past medical history was notable as he had been born with a cyanogenic heart anomaly (truncus arterious communis) which had been treated medically with furosemide and captopril until successful cardiac surgery, performed at 2 years of age. Following cardiac surgery, echocardiography with Doppler studies confirmed a successful repair, with no mixing of the arterial and venous blood. His cyanosis resolved and medical treatment was discontinued. Despite this apparently good outcome, he failed to thrive.

Upon admission to our unit, the boy was tachypneic, dehydrated and listless, with significant growth retardation [height $80 \mathrm{~cm}$ ( $-4.5 \mathrm{SD}$; weight $9.0 \mathrm{~kg}(-4.9 \mathrm{SD})$ ]. There was no cyanosis. Cardiac examination revealed a systolic murmur, grade III/IV, at the precordium. Ultrasound of the abdomen revealed no hepatosplenomegaly, and both kidneys were of normal size without dilatation of the pelvicaliceal system. A single non-obstructive stone measuring $10 \mathrm{~mm}$ was seen in the lower pole of the left kidney (Fig. 1) without evidence of generalized nephrocalcinosis. A repeat echocardiogram confirmed adequate repair of the cyanotic anomaly.

Laboratory investigations included a full blood count, revealing: hemoglobin $13.4 \mathrm{~g} / \mathrm{dl}$, erythrocytes $4.66 \times$ $10^{12} / 1$, leukocytes $8.6 \times 10^{9} / 1$, hematocrit $42.7 \mathrm{vol} \%$, platelets $344 \times 10^{11} / 1$. The results of the arterial blood gas analysis were: $\mathrm{pH} 7.12, \mathrm{pCO}_{2} 2.45 \mathrm{kPa}, \mathrm{pO}_{2} 12.7 \mathrm{kPa}, \mathrm{O}_{2}$ saturation $98 \%$. Serum electrolytes and liver and bone biochemistry test results were: $\mathrm{HCO}_{3} 10.1 \mathrm{mmol} / \mathrm{l}$, urea $4.1 \mathrm{mmol} / \mathrm{l}$, creatinine $9 \mu \mathrm{mol} / \mathrm{l}$, uric acid $116 \mu \mathrm{mol} / \mathrm{l}$, $\mathrm{Na} 145 \mathrm{mmol} / 1$, K $3.3 \mathrm{mmol} / 1$, Ca $2.23 \mathrm{mmol} / 1$, P $0.74 \mathrm{mmol} / \mathrm{l}, \mathrm{Mg} 1.0 \mathrm{mmol} / \mathrm{l}, \mathrm{Cl} 115 \mathrm{mmol} / \mathrm{l}$, alkaline phosphatase $762 \mathrm{U} / \mathrm{l}$, parathyroid hormone $33.3 \mathrm{pg} / \mathrm{ml}$ (normal 10-65), glycemia $4.6 \mathrm{mmol} / 1$, total protein $78 \mathrm{~g} / \mathrm{l}$, 
Fig. 1 Non-obstructive calculus in the left kidney

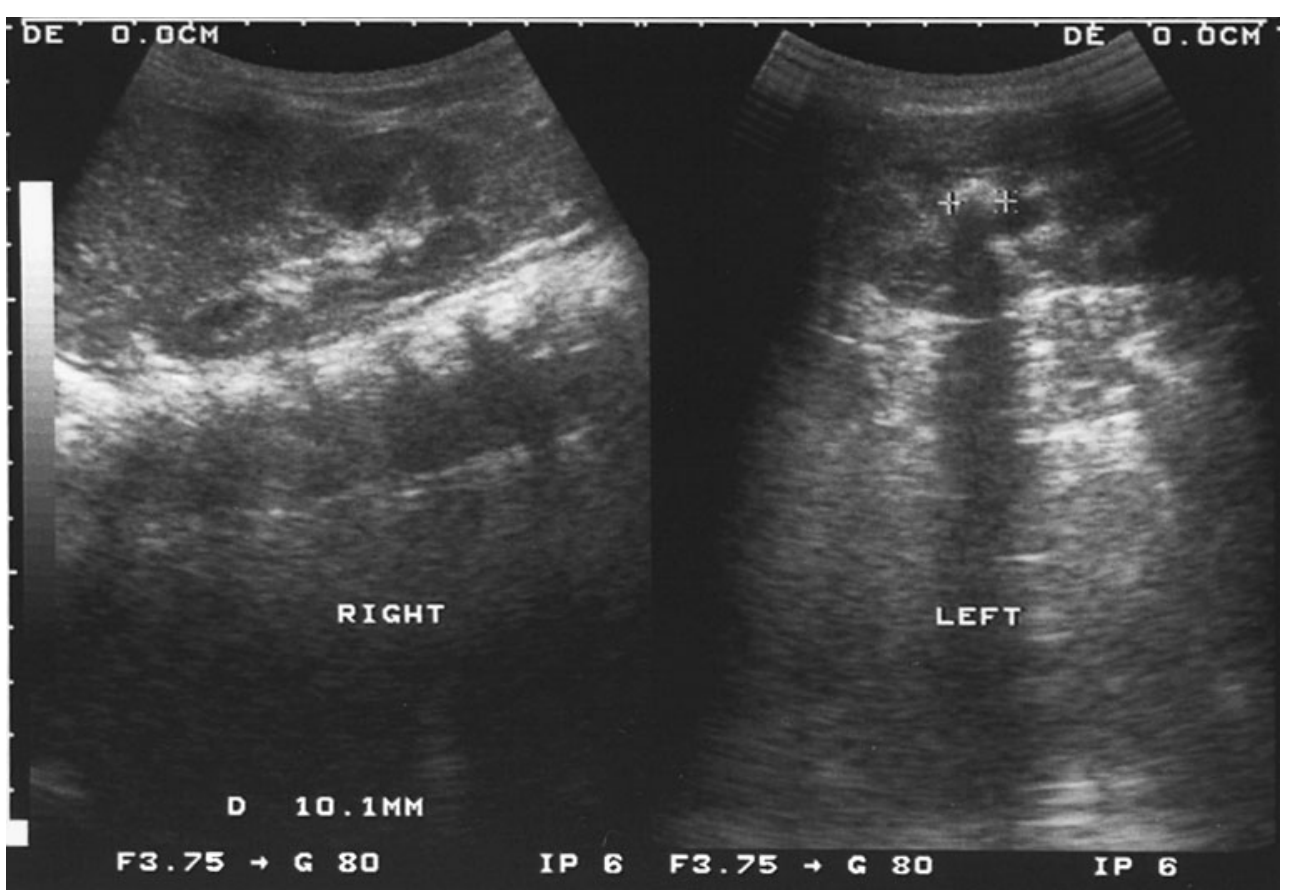

albumin $49 \mathrm{~g} / \mathrm{l}$, bilirubin $7 \mu \mathrm{mol} / \mathrm{l}$, aspartate aminotransferase $32 \mathrm{U} / \mathrm{l}$, alanine aminotransferase $17 \mathrm{U} / \mathrm{l}$, glutamic oxaloacetic transaminase $26 \mathrm{U} / 1$, lactate dehydrogenase 570 $\mathrm{U} / 1$, creatine phosphokinase $20 \mathrm{U} / 1$.

The spot urine examination revealed: protein $2+(1.07 \mathrm{~g} / \mathrm{l}$, electrophoresis of urinary proteins showed complete tubular proteinuria), blood 1+, $\mathrm{pH} 7.17$ (with electrode). Urinary electrolytes were as follows: $\mathrm{Na} 58 \mathrm{mmol} / \mathrm{l}, \mathrm{K} 37 \mathrm{mmol} / \mathrm{l}, \mathrm{Cl}$ $56 \mathrm{mmol} / \mathrm{l}$. The urinary calcium:creatinine ratio was elevated at $1.82 \mathrm{mmol} / \mathrm{mmol}$ (normal $<0.70$ ). Tubular reabsorption of phosphate and uric acid was 70 and $78 \%$, respectively. The nitroprusside reaction for urinary cystine was negative. The urinary oxalate:creatinine ratio was $215 \mathrm{mmol} / \mathrm{mol}$ (normal 35-126), urinary citrate:creatinine ratio was $80 \mathrm{mmol} / \mathrm{mol}$ (normal 150-1007), urinary glycolate: creatinine ratio was $24 \mathrm{mmol} / \mathrm{mol}$ (normal 17-103), and urinary glycerate was non-detectable. There was a generalized hyperaminoaciduria.
In addition to the above clinical findings, the findings of an ophthalmological examination were normal, and audiologic examinations excluded any sensorineural deafness. The patient was treated with oral potassium and alkali supplementation (K-citrate $10 \mathrm{mmol} / \mathrm{day}+\mathrm{NaHCO}_{3}$ $20 \mathrm{mmol} /$ day). At review 3 months later, the acid-base status, serum phosphate and uric acid had normalized as had the urinary excretion of proteins, oxalate, citrate, amino acids, calcium, phosphate and uric acid.

\section{Questions}

1. What is diagnosis of his tubular dysfunction?

2. What is the link between a cyanotic heart anomaly, failure to thrive and nephrolithiasis?

3. What is the explanation for the proximal renal tubular abnormalities? 